May-Britt Revheim Brekke

Høgskulen på Vestlandet

Marianne Leikvoll Eide

Høgskulen på Vestlandet

DOI: http://dx.doi.org/10.5617/adno.6910

\title{
Praksisfortelling, refleksjon og transformativ læring
}

\section{Sammendrag}

Denne artikkelen retter oppmerksomheten mot hvordan refleksjon og transformasjon kan fremmes gjennom praksisfortellingen som en studentaktiv laringsform $i$ pedagogikkundervisningen i lcererutdanningen. I arbeidet med praksisfortellingen bryter vi med en tradisjonell deduktiv tilncerming til undervisningen. I en profesjonsutdanning kreves det at man kan koble og utvikle et samspill mellom ulike kunnskapsformer, som en veksling mellom det partikulcre og det generelle. I dette arbeidet er overskridende refleksjon over egne forståelser og erfaringer vesentlig. Artikkelen tar utgangspunkt i deltakende observasjon på første trinn i Grunnskolelcrerutdanningen. Studien viser at det er flere forhold som kan påvirke kvaliteten til refleksjonen og den pedagogiske tenkningen. Dette kan dreie seg om kvaliteten til selve fortellingen, studentenes oppfatning av hva den pedagogiske teoriens funksjon er, og hvorvidt det utvikles et rom for utfordring og støtte. Refleksjonsprosesser kommer ikke automatisk, og må derfor settes i gang gjennom systematisk undervisning der det inviteres til utvidelse av egne erfaringer i møtet med generalisert kunnskap.

Nøkkelord: praksisfortelling, studentaktivitet, forholdet mellom teori og praksis, refleksjon, transformativ laring

\section{Experiential narrative, reflection and transformative learning}

\begin{abstract}
This article draws attention to how reflection and transformation can be promoted through experiential narratives as a student-active learning activity when teaching pedagogics in the teacher education. In our work on the experiential narrative, we have a different approach than the traditional deductive teaching method. In a professional education, it is required to be able to connect and develop an interaction between different forms of knowledge, such as an exchange between the particular and the general, where transcendent reflection on the students' own understandings and experiences is significant.
\end{abstract}


This article is based on participatory observation at the first level in teacher education, and finds that several factors affect the quality of the reflection and the pedagogical thinking. This includes the quality of the experiential narrative itself, the students' perception of the role of the pedagogical theory, and to what extent there is a room for challenge and support. One cannot expect that reflection processes come automatically or without support, but these processes can be initiated through systematic teaching that opens for expanding own experiences in the meeting with generalized knowledge.

Keywords: experiential narrative, student activity, relationship between theory and practice, reflection, transformative learning

\section{Innledning}

Denne artikkelen retter oppmerksomheten mot hvordan refleksjon og transformasjon kan fremmes gjennom arbeid med praksisfortelling som en studentaktiv læringsform. Formålet med studien er å undersøke hvordan bruk av praksisfortelling kan bidra til å utvikle refleksjonsevne ut fra egne erfaringer og relatert til mer generell pedagogisk teori. Begrepet 'praksisfortelling' viser til erfaringer fra praksis (Fennefoss \& Jansen, 2004), og refererer i vår sammenheng til hvordan erfaringer fra grunnskolepraksis trekkes inn i undervisningen på campus.

Kunnskap utvikles i et fellesskap, og betydningen av studentaktive læringsformer og samarbeid er vektlagt både politisk og faglig. Dette er forankret blant annet i Stortingsmelding 16 (2016-2017), Kultur for kvalitet i høyere utdanning: «Læring er en subjektiv prosess som skjer gjennom aktivitet og refleksjon i møtet mellom studenter og undervisere, og ikke ved at studentene passivt mottar kunnskap» (Meld. St. 16, 2016-2017, s. 17). Vi anser det å fremme transformasjon hos studentene som vesentlig for undervisningskvalitet (Wittek \& Habib, 2012), og ser læring som en kreativ prosess som bygger på både performativ og transformativ kunnskap. I en profesjonsutdanning kreves det at man kan koble og utvikle en sammenheng mellom ulike kunnskapsformer (Grimen, 2008; Heggen \& Raaen, 2014), og i dette arbeidet er refleksjon som overskrider egne forforståelser og erfaringer vesentlig. Solstad (2013) påpeker at refleksjon er av avgjørende betydning for at studentene skal kunne utvikle seg profesjonelt.

I artikkelen bygger vi på forskning som dreier seg både om praksisfortelling som læringsform og om utvikling av refleksjon og transformasjon. Praksisfortellinger har hatt en sentral plass i barnehagelærerutdanningen. Ifølge Ødegaard (2015) er praksisfortellinger, som utdanningshistorier, kilder til innsikt om utfordringer i en profesjonsrettet utdanning. Kunnskap fra barnehagelærerutdanningen kan ha verdifull overføringsverdi til vår kontekst i grunnskolelærerutdanningen, da disse to utdanningene har lignende utfordringer, blant annet knyttet til forholdet mellom teori og praksis. Eilifsen (2015) peker på at målet 
med praksisfortellinger i lærerutdanningen er å invitere til å gå inn i både erfaringsbasert og teoribasert kunnskap. Hensikten er da ikke å skaffe sikker viten som direkte kan anvendes i praksis, men å styrke sammenhengen mellom teori og praksis. Praksisfortellingen kan fungere som en læringsstrategi for lærerstudentene, ved at de setter ord på sine erfaringer innenfor en faglig ramme (Jansen, 2008), og gjennom tolkning og analyse av praksisfortellinger kan selvstendig refleksjon i læringsfellesskapet fremmes. Halmrast, Taarud og Østerås (2013) peker på at det er viktig å kunne utfordre seg selv og andre under arbeid med refleksjon og praksisfortelling, og at meningsforskjeller må vektlegges som grunnlag for endringsprosesser.

Undersøkelser indikerer at lærerstudenter verdsetter praksiserfaringer høyt, og at teoretisk kunnskap ikke oppleves som nyttig med mindre den kan inkludere tips som direkte kan anvendes i praktiske undervisningssituasjoner (Hovdenak \& Fosse, 2014; Eide, Brekke \& Holthe, 2017). Lærerprofesjonens allsidige kunnskapsgrunnlag kan fremstå som utydelig for studentene. Akademisk, teoretisk kunnskap og praktisk, erfaringsbasert kunnskap forståes ikke automatisk som en integrert helhet. Dette kan ha sammenheng med at lærerprofesjonens ulike kunnskapsformer kan sies å være knyttet til ulike logikker, der den teoretiske kunnskapen utvikles over tid, mens den praktiske kan ha et mer umiddelbart nytteperspektiv. Ifølge Klemp (2013) kan forståelse av forholdet mellom teori og praksis utvikles i ulikt takt for forskjellige studenter. Noen reflekterer på et kontekstnært nivå, mens andre i større grad kan abstrahere til et teoretisk symbolnivå. Fosse (2016) peker på at det i lærerutdanningen må utvikles metoder som kan gjøre det lettere for studentene å transformere erfaringsbasert kunnskap fra praksis over til mer generalisert, teoretisk kunnskap. Studentene har behov for kjennskap til pedagogiske teoriers ulike funksjoner. Blant annet kan pedagogisk teori bidra til å skape forståelser av praksis, som briller til å se og forstå med (Kvernbekk, 2011).

I en litteraturgjennomgang publisert i tidsskriftet Journal of Transformative Education finner Hatlevik (2018) at transformative læringsaktiviteter særlig kan fremme to kompetanseelementer. Det ene er evne til å reflektere kritisk over egne og andres antakelser når det gjelder profesjonsutøvelse. Det andre elementet dreier seg om økt bevissthet, spesielt relatert til forståelse av elever med ulike læreforutsetninger. Praksiserfaringer er ifølge Hatlevik en god inngang for initiering av transformative læringsprosesser. Selvopplevde erfaringer kan bidra til å skape motivasjon og vilje til endring. Når fortellingene angår dem selv, blir det meningsfullt for lærerstudentene å diskutere pedagogiske problemstillinger fra ulike synsvinkler. Åpenhet for endring har betydning for utvikling av lærerprofesjonalitet. Gjennom dialogen i den sosiale konteksten kan transformativ læring fremmes, når nye erfaringer kobles sammen med teoretisk og forskningsbasert kunnskap. Hatlevik (2018) hevder at teori om transformativ læring i liten grad er brukt i norsk og europeisk utdanningsforskning, og at det er behov for forskning om transformative læringsaktiviteter i norsk lærerutdanning. 


\section{Fokus og problemstilling}

Fokus for artikkelen er hvordan refleksjon og transformasjon kan fremmes gjennom arbeid med praksisfortelling som læringsform i pedagogikk og elevkunnskap (PEL) i grunnskolelærerutdanningen (GLU). Vi presenterer funn og drøfting på bakgrunn av deltakende observasjon i klasseromsundervisning, og med følgende problemstilling:

Hvordan kan arbeid med praksisfortellingen danne utgangspunkt for profesjonskunnskap og refleksjon hos lcererstudentene i pedagogikkundervisningen?

\section{Faglig opplegg med praksisfortelling som grunnlag for refleksjon}

Studenters refleksjon som verktøy for læring kan på ulike måter fremmes i deres første tid i lærerutdanningen, men ifølge Allas, Leijen og Toom (2017) har dette tidligere i liten grad vært satt i system. I en studie undersøker de et systematisk undervisningsopplegg, 'a guided reflection procedure'. Meningen med dette var at studentene skulle velge ut en erfart situasjon og se den i lys av ulike perspektiv, for deretter å relatere dette til teoretisk kunnskap. Formålet var å skape en kritisk og aktiv refleksjonsprosess i læringsmiljøet. I likhet med Allas et al. (2017) søkte vi å fremme refleksjon gjennom et systematisk undervisningsopplegg.

Praksisfortellingen var del av et arbeidskrav for lærerstudenter på GLU (5.10. trinn). Arbeidskravets første steg gikk ut på at hver praksisgruppe skulle utvikle en felles praksisfortelling, bygd på en systematisk observasjon og relatert til et valgfritt emne i PEL i det første studieåret. Andre steg var en individuell oppgave som bestod av at hver student i gruppen skulle gi en utdypende kommentar til fortellingen, hvor hendelsen(e) i fortellingen ble knyttet til pedagogiske fagbegreper og teorier. Muntlig presentasjon (av første og andre steg) skulle deretter danne utgangspunkt for refleksjon i klassens læringsfellesskap. I dette tredje steget skulle refleksjonsprosesser fremmes i klasserommet gjennom et vekselspill, der studentene lyttet og kunne komme med innspill, og vi som faglærere kunne følge opp med spørsmål. Intensjonen var å åpne rommet for stadig nye tolkninger.

Vi ønsket å fremme aktiv lytting under gruppenes fremlegg. Fennesfoss og Jansen (2004) presenterer en analyse- og tolkningsmetode som kan støtte studentenes refleksjonsprosesser under arbeidet med praksisfortellingen. Inspirert av deres beskrivelse utarbeidet vi et assosiasjonsskjema med refleksjonsspørsmål som studentene kunne bruke når de lyttet til fremleggene og i refleksjonssamtalen etterpå. Dette innebar at studentene først skulle assosiere fritt til praksisfortellingens budskap, deretter gå fra umiddelbare tanker og følelser til mer bevisst tenkning om fenomenene, for så å relatere praksisfortellingen til relevante fagbegreper, teorier, holdninger og verdier. 
I den kollektive refleksjonen etter fremføringene ble studentene oppfordret til å forstå fortellingen på ulike måter og ut fra ulike perspektiver. I refleksjonsprosesser er det et mål å finne mange mulige svar, og her har faglærer et viktig ansvar for å drive refleksjonsprosessen videre gjennom veiledende spørsmål (Korthagen \& Vasalos, 2005), og med å oppfordre til nytenkning.

Vår tilnærming til arbeidet med praksisfortellingene bryter med den tradisjonelle undervisningen som har vært preget av en deduktiv tilnærming, fra det generelle til det spesielle. Den tradisjonelle tenkningen kan blant annet knyttes til Ausubel, som argumenterer for en lærerstyrt, systematisk undervisning hvor læreren formidler generelle prinsipper, for deretter å gå til eksemplene (Ausubel, 2000). Transformativ læring krever læreprosesser som balanserer mellom det særegne (konkrete) og det generelle, og dermed mellom det induktive og det deduktive. Gjennom refleksjonsprosesser som søker å koble ulike kunnskapsformer, skapes forutsetninger for utvikling av lærerprofesjonalitet (Eraut, 2004; Grimen, 2008; Heggen \& Raaen, 2014; Fosse, 2016). Ifølge Eraut (2004) er lærerutdannere i for liten grad opptatt av å støtte studentene i prosessen med å koble den praktiske og den teoretiske kunnskapen.

\section{Teoretisk rammeverk}

\section{Refleksjon og transformativ læring}

For å lære av erfaringen må man gjennom en aktiv refleksjonsprosess. Erfaring gir ikke læring i seg selv (Dewey, 1974). Refleksjon kan omtales som en tenkning som består i å vende et tema i hodet, for så å underkaste det en alvorlig og sammenhengende overveielse (Dewey, 1933). Det er et vesentlig poeng for Dewey at noe må føres inn i tenkningen, noe som utfordrer den umiddelbare forståelsen, og som får en til å tenke på nytt. Han er opptatt av at det må skje en overskridelse, en transcendental tenkning, for at erfaringen skal gi læring. Som en konsekvens av dette må studentene trenes i å undersøke og utfordre det de har erfart (Brekke, 2017). Dette kan være en tidkrevende prosess, og det kreves et romslig læringsmiljø hvor studentene får øvelse i å både gi og ta imot kritikk (Borko, 2004).

Gjennom refleksjonen kan vi skape en distanse til egen vanetenkning og forforståelse, og dette gir dermed nye muligheter for fortolkning og transformasjon av læring. Transformativ læringsteori bygger på et konstruktivistisk læringssyn. Individet skaper mening innenfor et sosialt og kulturelt fellesskap, og på denne måten, gjennom tolkning, utvikles forståelse i lys av tidligere erfaringer (Mezirow, 1997). Læring forstås som en prosess «... of making a new or revised interpretation of the meaning of an experience, which guides subsequent understanding, appreciation and action» (Mezirow, 1990, s. 1). Tidligere erfaringer har skapt forventning som påvirker vår forståelse av en situasjon. Disse erfaringene åpner for muligheter, men kan også begrense vårt synsfelt. Gjennom refleksjonen 
kan vi skape en avstand til egne forventningsvaner, og dette gir dermed nye muligheter for fortolkning. Når noe oppleves som uklart, kan det oppstå en dissonans som setter i gang refleksjon, og i noen tilfeller fører dette til at forforståelsen utfordres og tidligere meningsperspektiv eller referanseramme endres (Mezirow, 1990). Transformasjon kan skje som en gradvis prosess, eller som en transformasjon utløst av en krise eller et dilemma (Mezirow, 1990; Illeris, 2012). I situasjoner hvor forforståelsen utfordres, kan forsvarsmekanismer settes i gang (Mezirow, 1990).

Mezirows teori om transformativ læring har blitt kritisert for å ha et for stort fokus på individet og bevissthetens rolle, samt at betydningen av affektive forhold er underkommunisert (Lin \& Cranton, 2005). Følelser, opplevelser og samspill har en nedtonet plass. Illeris (2012) utvider perspektivet til Mezirow, idet han vektlegger den emosjonelle siden ved transformativ læring. Ifølge Illeris må drivkraftsdimensjonen i transformativ læring inkluderes, da motivasjon, følelser og vilje er grunnleggende for å kunne involvere seg i lærings- og endringsprosesser. Mezirow (1990) har besvart deler av kritikken. Han hevder at det er i enkeltindividets bevissthet endringen kan initieres, men at andre forhold kan ha betydning for transformasjon. Blant annet trekker han frem nødvendigheten av trygghet, åpenhet og tillit i slike læringsprosesser. På bakgrunn av dette var det viktig for oss å tone ned vurderingsaspektet ved arbeidskravet, og vi presiserte at vi ikke var ute etter forhåndsbestemte svar på oppgaven. Rappel (2018) påpeker at behovet for å «gjøre det riktige» kan stå i veien for refleksjon og kritisk vurdering.

Selv om refleksjon kan forstås som en subjektiv prosess hvor en utvikler sin kognitive bevissthet, så er det intersubjektive en vesentlig del av denne prosessen. Ifølge ulike studier (Daudelin, 1996; Procee, 2006; Allas et al., 2017), er refleksjonsprosessen enda mer produktiv når det er rom for diskusjoner sammen med andre. Andre mennesker kan tjene som «katalysatorer» for refleksjon (Daudelin, 1996), og dermed være med å utvikle forestillingsevne hos den enkelte. Hvis man kun vender blikket mot seg selv i en refleksjon, kan det oppstå en form for narsissisme, advarer Arendt (1996). Dette omtaler hun som «refleksjonens onde tvilling». Skal det skje en transformativ, overskridende tenkning, så må man få fatt i den Andres forestillingsverden, slik at det blir mulig å få andre sine blikk på egne erfaringer. Dette kan forhindre at forståelser og forklaringer går i sirkel. Derfor er det viktig for oss i vårt arbeid at studentene får dele erfaringer og tolkninger med hverandre.

\section{Praksisfortelling som læringsform}

Erfaringer utspiller seg i kontekster og situasjoner, og nærhet til slike erfaringer skaper forutsetninger for å kunne delta aktivt i undervisning (Dewey, 1974). Sanseinntrykk, handlinger og tenkning inngår for Dewey i en helhet. Erfaringer er av både fysisk og intellektuell karakter, og som en integrert helhet legges det et grunnlag for å lære av sine erfaringer gjennom overveielser. 
Når lærerstudenter uttrykker sine erfaringer gjennom den narrative formen, tar de i bruk den tidligste og mest naturlige formen for organisering av erfaring og kunnskap (Bruner, 1997). A skape fortellinger er en universell menneskelig aktivitet. For å forstå hvordan noe henger sammen, vil vi skape forbindelser gjennom narrativer (Gudmundsdottir, 1996). Den etymologiske betydningen av «narrativ» kommer fra det latinske narrare, å fortelle, og gnarus, å ha kunnskap om noe, ha kjennskap til noe, eller være fortrolig med noe som er lært gjennom erfaring (fritt oversatt etter Kvernbekk \& Frimannsson, 2013).

Det å sette ord på en opplevelse i klasserommet, kan vekke engasjement og bidra til at lærerstudenten går dypt inn i en situasjon. Gjennom språket skapes mening og mengden av sanseinntrykk samles til noe som er begripelig, sier Dewey (1974). Det kreves bevisst bruk av ord og begreper for å skape en kronologisk og logisk fortelling med start, midtdel og slutt (Bruner, 1997; Gudmundsdottir, 1996; Fennefoss \& Jansen, 2004). En historie vil ha to sider; en som uttrykker en sekvens av hendelser og en innebygget evaluering av disse hendelsene. Noe velges vekk, noe annet vektlegges. Utvalgt informasjon om sted, tid og den sosiale og kulturelle konteksten blir presentert. Historien er ikke oppdiktet, da en reell konkret situasjon danner utgangspunktet for praksisfortellingen. Den vil uttrykke et budskap ut fra fortellerens synsvinkel (Bruner, 1997). Den vil være subjektiv, men sann for den som forteller, og fortelleren vil være opptatt av å formidle sin forståelse av opplevelsen i skrivende stund. Slik blir fortellingens budskap gjort tilgjengelig for leseren og lytteren. Ved å kategorisere fortellinger kan momenter som fortelleren har vektlagt, lettere løftes frem (Birkeland, 2004). Ifølge Birkeland kan fortellinger deles inn i ulike fortellingstyper, i tråd med tolkning av budskapet. Fortellinger kan være rene 'solskinnshistorier' der fortelleren gjør barnet til helten i fortellingen, eller 'suksessfortellinger' der det skinner gjennom hvordan et vellykket pedagogisk resultat er nådd gjennom hardt og målrettet arbeid.

Kategorien 'vanefortellinger' kjennetegnes ved at vanlige, innarbeidete historier om et fenomen kommer til uttrykk. I skolens kontekst kan det for eksempel utvikles en forståelse av at noen elever er «vanskelige» av natur. Denne type fortellinger kan også relateres til det som Kvernbekk (2001) kaller commonsensiske teorier. Slike teorier rommer forestillinger som har fått feste som et slags felleseie i kulturen, som man oppfatter som sanne og ikke lenger stiller spørsmål ved. Men i Birkelands (2004) kategori 'vendepunktfortellinger' skjer det, som navnet sier, noe som endrer forståelsen. Det kan være overraskelser og nye oppdagelser i møtet med barnet. Fortelleren har endret oppfatning av situasjonen og åpnet for nye tankebaner underveis, slik at en mer åpen og romslig holdning til barn kommer til uttrykk.

Når en fortelling blir utarbeidet, finnes det både nærhet og avstand til erfaringen, og en bevissthet om situasjonen er skapt. Fortellingen har på denne måten en egenverdi. Men ved å dele praksisfortellinger og hvordan situasjoner på ulik måte kan kobles til teori, kan praksisfortellinger få større betydning enn deres 
egenverdi i utgangspunktet. Nye fortellinger og ny pedagogisk forståelse skapes. Den første historien om en hendelse viser fortellerens tolkning av et lite utsnitt av en situasjon, ikke hele virkeligheten (Gudmundsdottir, 1996). Det er allerede en gjenfortelling, og lytteren kjenner ikke opprinnelsen. Situasjonsbildet kan ytterligere gjenfortelles, og ifølge Gudmundsdottir få stor innflytelse på læreres og lærerstudenters praksis gjennom «re-storying» som en fortolkende prosess. Fortellerne, i vår sammenheng studenter og lærere, kan i fellesskap utforske enkelthendelser slik at disse gir en dypere mening, eller utdype det narrative perspektivet slik at det kan generaliseres og overføres til andre kontekster. Bevissthet om den opplevde situasjonen eller hendelsen legger et grunnlag for at studentene kan reflektere og skape sammenhenger mellom praksis og teori i klassens læringsfellesskap.

Man kan diskutere om begrepet 'praksisfortelling' er uheldig fordi det kan sementere oppfatningen av praksis som motsats til teori (Ødegaard \& Birkeland, 2001). Men i vår sammenheng er erfaringshistorier fra praksis nettopp et utgangspunkt for å tydeliggjøre sammenhenger mellom teori og praksis, og hvordan ulike kunnskapsformer kan utfylle hverandre etter hvert som fortellinger blir konstruert og rekonstruert i et vekselspill.

Det at erfaringer bearbeides, deles med andre og kobles til relevant teori, vil ha betydning for kvaliteten til refleksjonen. Nye stemmer og nye innspill vil utfordre oppfatningen av den konkrete situasjonen, og slik kan førsteårsstudenter få lære av hverandres erfaringer, noe som kan hjelpe dem å tolke, re-tolke og videreutvikle sine egne perspektiver (Gudmundsdottir, 1996). Faglærers veiledning og medstudenters kritiske spørsmål kan bidra til å forbedre refleksjonen, fra en ren beskrivelse av praksis til en mer kritisk evaluering og ny innramming av tidligere forståelse (Allas et al., 2017). Refleksjon gjennom interaksjon assosieres på denne måten med et støttende miljø og et rom for kritiske innspill.

Hensikten med praksisfortellingen som læringsform er å skape vekselspill mellom praktiske erfaringer og mer generalisert kunnskap. I dette arbeidet må den første tolkningen og forståelsen utfordres og videreutvikles til ny innsikt og forståelse. Studentenes læring kan ha ulike startpunkt og overgangsbevegelser når de gjennom aktiviteten i klasserommet stadig kan forstå praksisfortellingene på nye måter. Ifølge von Oettingen (2012, s. 28) er negasjoner vesentlige i læringsprosessen: «Læringen opstår, hvor vi opplever eller erfarer, at verden ikke er som vi troede, den var.» Ifølge Burchell og Dyson (2000) kan fortellinger fungere som verktøy for refleksjon gjennom at dilemmaer og motsetninger synliggjøres. I klassens refleksjonsøkt er det slik lagt til rette for at studentenes forhåndsantakelser kan bli utfordret og motsagt. 


\section{Metode}

Denne artikkelen dreier seg om aksjonsforskning i tre klasser på første trinn i Grunnskolelærerutdanningen 5-10. Aksjonsforskning innebærer å identifisere et problemområde, forestille seg en løsning, prøve denne ut, for så å evaluere resultatet (Ulvik, Riese \& Roness, 2012). Vi undersøkte studentenes læringsprosess i arbeidet med praksisfortellingen i klasserommet. Dette ble gjort ved å observere studentenes muntlige fremlegg, respons, drøfting og refleksjon slik dette kom til uttrykk.

Som datainnsamlingsmetode brukte vi deltakende observasjon. Vi hadde en dobbeltrolle i disse tre undervisningsøktene. Som faglærere ledet vi hele undervisningsøkten som var på tre timer, og la til rette for presentasjoner og spørsmål. Det var viktig for oss å gjennomføre økten på en god måte, så naturlig som mulig. I tillegg gikk vi inn i observatørrollen, der vi i varierende grad var deltakende observatører. Dette kan knyttes til en innside/utside-problematikk (Fangen, 2010). Det vil si at oppgaven for oss var å balansere på en god måte mellom det å forstå fra innsiden, med vår kunnskap og forforståelse, og samtidig søke å få en nødvendig distanse fra et forskerperspektiv.

Det er i spennet mellom nærhet og distanse kvalitative undersøkelser foregår (Creswell, 2014), og gjennom å forske i eget nærmiljø, skapes et godt utgangspunkt for å forstå lokale prosesser (Fangen, 2010). Vår nærhet til miljøet innebærer god kjennskap til læringskulturen vi undersøker, samtidig som tolkningen av datamaterialet vil være verdiladet. En styrke ved deltakende observasjon er at forskeren får direkte tilgang til informantenes handlinger og meningsytringer mens de foregår (Cresswell, 2014). Vi risikerer imidlertid å gå glipp av vesentlig informasjon når vi selv er aktive deltakere i læringskonteksten. Det kunne vært en styrke å supplere med video-opptak for å få mulighet til å observere situasjonene i ettertid.

\section{Datagrunnlaget}

Formålet med observasjonen var å undersøke hvordan studentene reflekterte med utgangspunkt i praksisfortellingen, og hvordan de koblet praktiske erfaringer til pedagogisk teori. Vårt utvalg bestod av 3 klasser, med totalt 23 studentgrupper. Utvalget ble gjort ut fra tilgjengelighet. I hver studentgruppe var det fire studenter som hadde vært sammen i praksis. Vi var to faglærere som observerte i egen undervisning (hver av oss observerte alene i sine egne klasser). Observasjonen var systematisk og delvis strukturert. Utgangspunktet var noen forhåndsbestemte fokuspunkter som ble brukt ved hver gruppefremføring, som vist i skjemaet under: 


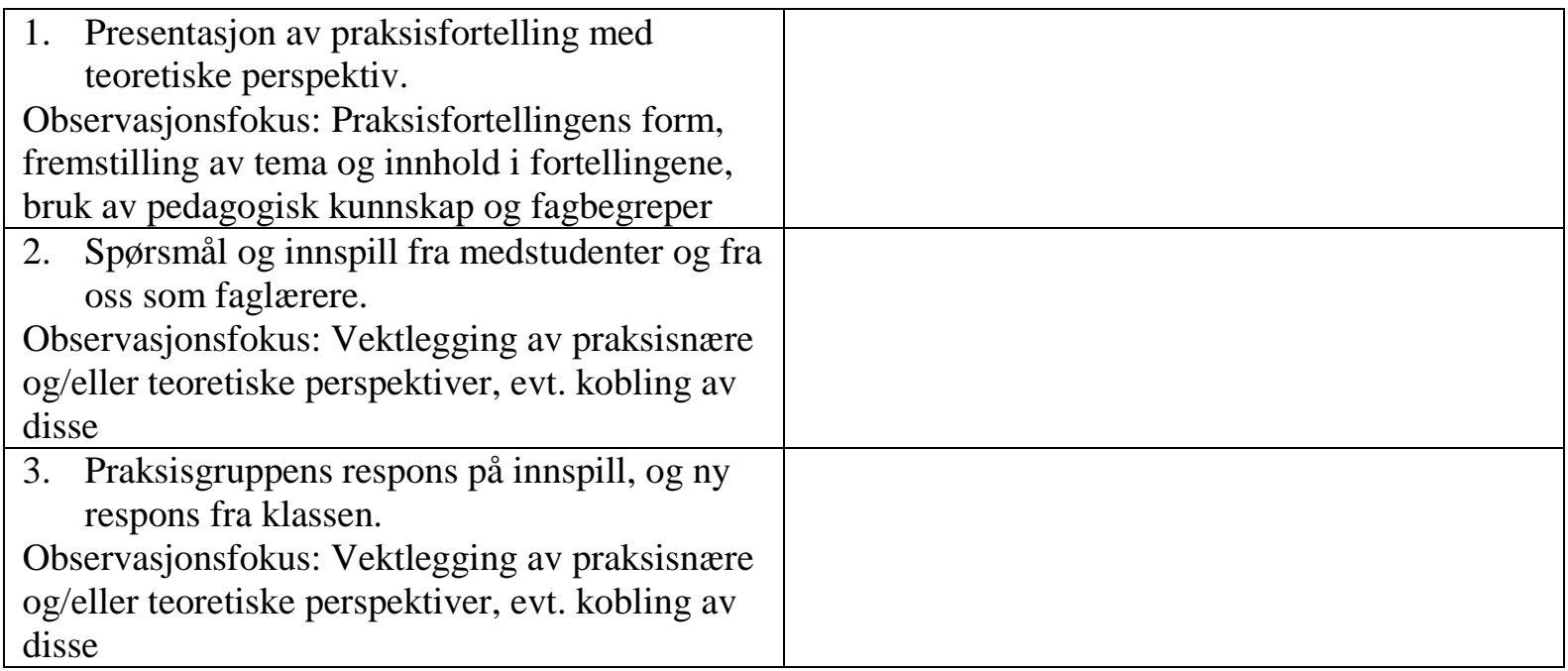

Figur 1. Strukturert observasjonsskjema

Åpenhet for det som oppstår, er karakteristisk for den kvalitative forskningsprosessen (Creswell, 2014). Det var derfor vesentlig å fange opp det umiddelbare som skjedde i refleksjonsøkten. Observasjonene ble ført som såkalte «jotted notes» (Lofland \& Lofland, 2006, s. 90). Slike notater er skriblerier vi som observatører fører underveis. Dette kan være nøkkelord, hele setninger, korte fraser, sitater o.l. som kunne hjelpe oss å huske når det kom frem noe av betydning knyttet til tematikken vår. Styrken ved vår deltakende observasjon er nærhet til det vi observerer.

\section{Dataanalyse}

Analyseprosessen vekslet mellom en induktiv og en deduktiv tilnærming, idet vi gikk frem og tilbake mellom relevant teori og datamaterialet. I analysen tok vi utgangspunkt i både det strukturerte observasjonsskjemaet vi hadde benyttet (jf. skjemaet over) og de friere notatene våre. Analysen søkte å fange opp både fenomen som gjentok seg på tvers av gruppene (frekvens), og spesifikke enkelterfaringer fra den enkelte gruppe. Denne delen av analyseprosessen kan beskrives som førstegradsfortolkning, der vi konstaterte ulike sider ved det vi observerte, i en beskrivende form (Fangen, 2010). I den videre analyseprosessen søkte vi å kategorisere datamaterialet i samsvar med problemstillingens fokus: å finne ut hvordan arbeidet med praksisfortellingen kan fremme refleksjon og profesjonskunnskap i pedagogikkundervisningen. Gjennom en åpen koding ble datamaterialet brutt ned og kategorisert (Kvale \& Brinkmann, 2015). I dette arbeidet var vi ute etter å oppdage mønstre i materialet og identifisere noen kjernekategorier. Denne delen av analysen kan omtales som andregradsfortolkning (Fangen, 2010), der vi fjernet oss stadig mer fra rådatamaterialet ved å generalisere og systematisere det vi hadde observert. Gjennom analysen kom vi frem til tre funnkategorier: a) Praksisfortellingens kvalitet og budskap, b) Utvidelse av tema og innhold i fortellingene, c) Teoriens funksjon. 


\section{Etiske betraktninger}

Studentene var muntlig informert om at observasjonene ville bli brukt i forskningsøyemed, og gav sitt muntlige samtykke til deltakelsen. I samsvar med prinsippet om informert fritt samtykke (www.etikkom.no) hadde studentene mulighet til å trekke seg fra undersøkelsen. I utarbeidelsen av resultatdelen har studentenes anonymitet blitt sikret, slik at studentene og deres historier ikke kan identifiseres. Fortellinger er omarbeidet for å kunne illustrere funn (Fangen, 2010). Dermed kan ikke teksten avsløre, verken direkte eller indirekte, personidentifiserbare opplysninger, i tråd med retningslinjer for personvern og deltakende observasjon (www.nsd.no).

\section{Resultater og drøfting}

I denne artikkelen stiller vi spørsmålet: Hvordan kan arbeid med praksisfortellingen danne utgangspunkt for profesjonskunnskap og refleksjon hos lcererstudentene i pedagogikkundervisningen? Resultatene fra undersøkelsen viser både styrker og kritiske aspekter ved undervisnings- og læringsprosesser observert i klassenes refleksjonsøkter. I denne delen presenteres funn og drøfting angående ulike forhold som kan påvirke kvaliteten til refleksjonen, i tråd med kjernekategoriene vi identifiserte under analyseprosessen. Dette dreier seg om a) Praksisfortellingens kvalitet og budskap, b) Utvidelse av tema og innhold i fortellingene, og c) Teoriens funksjon. Funn og drøfting settes i en helhetlig sammenheng under overskriften Rom for refleksjon.

\section{Praksisfortellingens kvalitet og budskap}

Analysen viste ulik kvalitet ved fortellingene når det gjelder fortellingsstruktur, form og gjennomarbeiding. Noen grupper fortalte om sine observasjoner uten å gå veien om en strukturert praksisfortelling. Andre grupper formidlet situasjoner fra klasserommet via en mer tydelig fortellingsform. Gjennom å strukturere fortellingen var det fra disse gruppene gjort aktive valg for å få frem budskapet i fortellingene. Dette er essensielt i arbeidet med å bli bevisst erfaringene sine (Dewey, 1974; Bruner, 1997; Gudmundsdottir, 1996; Kvernbekk \& Frimannsson; 2013). Strengt tatt var det ikke alle gruppene som formidlet en fortelling slik arbeidskravet omtalte dette. Men når det gjelder førsteårsstudenter er det rimelig å legge til grunn en vid og romslig forståelse av oppdraget. Ut fra våre observasjoner fremstod de strukturerte praksisfortellingene som mer spisset, mer avgrenset og mer samlet enn andre av de muntlige fremleggene, bl.a. fordi dilemmaer og meningsfulle situasjoner tydeligere kom til syne og forsterket budskapet i historien (Burchell \& Dyson, 2000). Dette gir et signal om at arbeidet med praksisfortellingens kvalitet når det gjelder innhold og form, i større grad må vektlegges når observasjonen skal omdannes til en narrativ erfaring. For å fremme 
transformativ læring kunne arbeidskravets oppgavebeskrivelse tydeliggjort betydningen av å ta med spenninger og motstand i fortellingene.

Observasjonene viste ulikt engasjement knyttet til fortellingene. Noen fortellinger og teoretiske innspill åpnet for refleksjon og ulike forståelsesmåter i større grad enn andre. For eksempel var det en del fortellinger som tydelig formidlet praksislærers gode evne til å håndtere uro eller drive engasjerende undervisning i klassen. Det kom også en del historier om utfordringer med å takle innspill fra elever og å få oppmerksomhet i klassen, og eksempler på hvordan de som lærerstudenter mestret dette. Slike fortellinger kan inngå i kategorien 'suksessfortellinger' (Birkeland, 2004), der god undervisning ble formidlet som en følge av lærers innsats og pedagogiske arbeid. Engasjement knyttet til slike fortellinger kan forklares med at budskap eller dilemma ble tydelig formidlet (Bruner, 1997; Gudmundsdottir, 1996). Respons på denne type fortellinger kan også forklares med at tematikken kunne være gjenkjennelig, og følgelig være lettere å respondere på enn i fortellinger der det var vanskelig å få tak på hva budskapet var.

Våre funn tyder på at det var et større engasjement knyttet til fortellinger som skapte gjenkjennelse. Gjenkjennelse av erfaringer gjør det lettere å koble seg på fortellingen, slik at refleksjonen settes i sving, og motivasjonen og viljen til endring øker (Hatlevik, 2018). Det er avgjørende at studentene oppfatter temaene som relevante og meningsfulle. Den subjektive opplevelsen når man selv forteller, og når man lytter til en fortelling, bidrar til meningsskaping. Det at historiene startet som subjektive erfaringer, kan også gi utfordringer, dersom det personlige utgangspunktet gjør at studentene får et eierforhold til «sine» fortellinger, og dermed ønsker å forsvare disse (Mezirow, 1990).

En fortelling som gjentok seg i alle de tre klassene, dreide seg om utfordringer i møtet med elevmangfoldet, ofte skildret ved hjelp av begrepene «svake» og «sterke» elever. Vi observerte engasjement og frustrasjon blant studentene når vi som faglærere problematiserte språkbruken i denne forbindelsen, illustrert ved en ytring fra en student: «Men hvordan skal vi snakke om elevene da?» Som faglærere utfordret vi budskapet i slik fortellinger, som kan kategoriseres som 'vanefortellinger' (Birkeland, 2004). I disse situasjonene ble studentenes forforståelse og meningsperspektiv utfordret (Mezirow, 1990), og slik ble det skapt et rom for nye tolkningsmuligheter og økt bevissthet rundt elever med ulike læreforutsetninger (Hatlevik, 2018). I denne prosessen ble den kognitive forståelsen av situasjonene problematisert, og samtidig ble følelser satt i sving hos studentene.

\section{Utvidelse av tema og innhold i fortellingene}

Tematisk dreide et flertall av fortellingene seg i utgangspunktet om historier rundt uro i klasserommet, utfordrende elevatferd, konfliktfylte relasjoner og krevende klasseledelse. Slike fortellinger kan kategoriseres innenfor kategorien 'vanefortellinger' som ifølge Birkeland (2004) er kjennetegnet ved vanetenkning, eller det Kvernbekk (2001) omtaler som commonsensiske teorier. I vår kontekst kunne 
slike fortellinger være farget av forestillinger om at noen elever har stabile egenskaper som gjør det vanskelig for dem å innordne seg i klassen, og at slike elever bevisst søker å forstyrre undervisningen med det resultat at det oppstår manglende læringsfokus i klassen. Denne type fortelling har et tydelig, subjektivt budskap (Bruner, 1997; Gudmundsdottir, 1996).

Vi observerte at når studentene bidro med hvert sitt teoriperspektiv, kom en annen og mer breispektret fortelling til syne. Hver student utfylte fortellingen, og gav den nye lag med informasjon til konteksten og forståelsen av situasjonen. Noen ganger endret bildet seg da nye innspill og spørsmål ble lagt til de opprinnelige fortellingene. Det som i utgangspunktet var nokså ukritiske vanefortellinger, ble til 'vendepunktfortellinger'. Ifølge Birkeland (2004) kjennetegnes slike ved nye oppdagelser i møtet med barnet. I refleksjonsøkten som vi observerte, oppdaget vi noen slike vendepunkt.

En bearbeidet historie fra studentenes presentasjoner kan tjene som eksempel på utvidelse, eller rekonstruksjon, av praksisfortelling. Denne fortellingen handler om en urolig elev som ikke deltar i undervisningsaktiviteter, og som stadig og impulsivt engasjerer seg i ulike utenomfaglige aktiviteter. Gutten beskrives som rastløs og høyrøstet, faglig passiv, men aktiv og engasjert når han prøver å skape liv og leven i klasserommet. Eleven vinner stadig slaget om oppmerksomheten i klassen, forteller studentene. Fortellingen fremstår som et eksempel på frustrasjon over enkelteleven som skaper vansker for læringskulturen og arbeidsroen i klassen, og kan i utgangspunktet betraktes som en 'vanefortelling' (Birkeland, 2004). Elevens negative atferd som problem i undervisningen er hovedbudskap i fortellingen. Så kommer studentenes innspill som nye lag i fortellingen, der fortellingen tolkes på nytt i lys av teori. Den første studenten viser til teori om observasjon som fortolkning, og utfordrer den opprinnelige fortellingen ved å påpeke at det kan finnes flere mulige forståelsesmåter. Den andre studenten trekker inn den didaktiske trekanten, og viser til hvordan elevens atferd gjør det vanskelig for læreren å få fokus på det faglige innholdet i timen. Her kan det se ut som om den didaktiske modellen blir brukt for å bekrefte budskapet i historien. Den tredje studenten trekker så inn manglende motivasjon, og søker å forstå fortellingen på en alternativ måte. Her blir det vist til teori om betydningen av at undervisning treffer elevens interesseområde, og at en gjennomtenkning av dette kunne ha forebygget problemet. Den fjerde studenten viser til en mulighet for at det bak elevens manglende motivasjon, konsentrasjon og faglige fokus kan skjule seg utfordringer når det gjelder tilpasset opplæring og forståelse av denne elevens behov.

I den kollektive refleksjonsprosessen etter hvert innlegg var det lagt opp til diskusjoner i klasserommet, hvor medstudenter og faglærere kunne komme med kritiske innspill, assosiasjoner og spørsmål. Under lyttingen til de andres presentasjoner, hadde studentene det utdelte assosiasjonsskjemaet med konkrete fokusspørsmål fremfor seg (jf. s. 3). Ved hjelp av dette skjemaet og våre innspill som faglærere, var alle i klassen aktive deltakere med innspill til læringsfellesskapet. 
Det er sentralt at faglærer og medstudenter kommer med kritiske innspill som kan sette refleksjonen i sving, slik at den kan løftes opp fra den konkrete erfaringen og gi grunnlag for nye forståelsesrammer (Allas et al., 2017; Burchell \& Dyson, 2000).

Vi observerte noen tilfeller der medstudenter gjenkjente egne erfaringer i andres fortellinger, for eksempel i møte med elevmangfoldet som tidligere omtalt, slik at det skjedde en kobling mellom fortellingene fra ulike kontekster. Nye historier ble skapt når studenter som lyttet, tok med seg sine praktiske og teoretiske erfaringer inn i klassesamtalen. Slik kunne fortellingene igjen forstås på nytt (Gudmundsdottir, 1996), og det ble åpnet opp for å se flere og andre sider ved situasjonen enn den som først var opplagt (Mezirow, 1990; Dewey, 1933; Arendt, 1996). På denne måten ble vanetenkning utfordret også i det kollektive rommet.

\section{Teoriens funksjon}

Vi fant, som nevnt over, at fortellingene ble utvidet når hver student bidro med sitt teoriperspektiv, selv om det var variasjon i hvordan teoretisk kunnskap ble utdypet i presentasjonen. Noen studenter vendte stadig tilbake til den konkrete praktiske erfaringen, mens andre i større grad trakk inn faglige begreper og teoretiske perspektiver. Vi observerte at flere av studentene hentet inn teoretiske perspektiver som støttet opp og bekreftet budskapet de formidlet. På en av gruppene ble det for eksempel sagt at «... læreren sin klasseledelse hellet mot den såkalte ‘classroom-management-tradisjonen’, da lærer prøver å holde det stille og rolig i klassen, og reagerer hurtig mot atferd som ikke er i henhold til klassereglene». På denne måten fikk de teori og erfaring til å «passe» sammen.

De fleste studentene brukte teorien på denne måten. Men vi observerte også eksempler på at bruk av teorien førte til at perspektivet ble endret. Fra å se på elevenes atferd som et problem, ble for eksempel oppmerksomheten flyttet fra eleven til lærerrollen. En studentgruppe viste til forskning om «teachereffectiveness-tradisjonen» og stilte seg ulike spørsmål som dreide seg om lærerens undervisningsholdninger: «Kanskje eleven ikkje er så interessert i dette stoffet?» og «Kanskje lærar kunne organisert undervisninga på ein annan måte for at det skulle vere meir motiverande for eleven å jobbe?» Disse sitatene illustrerer hvordan teorien ble brukt for å utfordre den første fortellingen. Førsteårsstudenter kan ha lite erfaring med at pedagogiske teorier kan ha ulike funksjoner. Pedagogiske teorier kan brukes til å beskrive, forklare eller foreskrive praksis, men kan også brukes til å forstå eller diskutere med slik at den pedagogiske tenkningen utvikles (Kvernbekk, 2001; Solstad, 2013). Teorier kan dermed gjøre en i stand til å innta et kritisk perspektiv og skape en distanse til selve erfaringen. Vi fant at studentene gjorde dette i ulik grad, og vi observerte at studentene vekslet mellom bruk av teoretiske begreper og hverdagsbegreper både i fremleggene og i diskusjonene. 
For å få et godt utbytte av arbeidet med refleksjon, slik at det blir et vekselspill mellom det induktive og det deduktive, kan førsteårsstudenter trenge en viss forståelse av grunnleggende teori og faglig begrepsapparat (Allas et al., 2017). Med et begrenset begrepsapparat blir det færre muligheter for tolkninger og valg av perspektiver. Studentenes utvikling av forståelse av forholdet mellom teori og praksis skjer ikke på lik måte for alle studenter (Klemp, 2013). Hvis studentene får trening i refleksjon over tid, hvor de tar i bruk didaktisk kunnskap og et profesjonelt fagspråk knyttet til sine egne praktiske erfaringer, vil dette ha en utviklende funksjon. Det kan være en krevende oppgave å forstå forholdet mellom konkrete enkelteksempler og mer generalisert kunnskap, og forholdet er heller ikke statisk. Det er derfor nødvendig at arbeid med begrepsutvikling begynner tidlig, og det må foregå kontinuerlig gjennom lærerutdanningen.

Samtalen etter presentasjonen var like viktig for studentenes læring som presentasjonen, for å kunne overskride eller utvide tenkningen. Derfor ønsket vi ikke å la klasseromsøkten stoppe med de muntlige fremleggene. Det å slippe nye innspill til, kunne skape en form for tvil (Dewey, 1933) som kunne sette nye tanker i sving. I klassens felleskap hvilte det ikke bare på den enkeltes fortolkning og forståelse. Gjennom kollektiv abstraksjon og begrepsformulering ble erfaringen løftet fra det partikulære til en mer generell innsikt (Daudelin, 1996; Procee, 2006). Dette er søkt fremstilt gjennom en modell (figur 2) som viser arbeidet med praksisfortellingen og kobling til relevant teori gjennom den første refleksjonsprosessen, og videre en ny modell (figur 3) som illustrerer den kollektive refleksjonen frem mot transformasjon og ny forståelse.

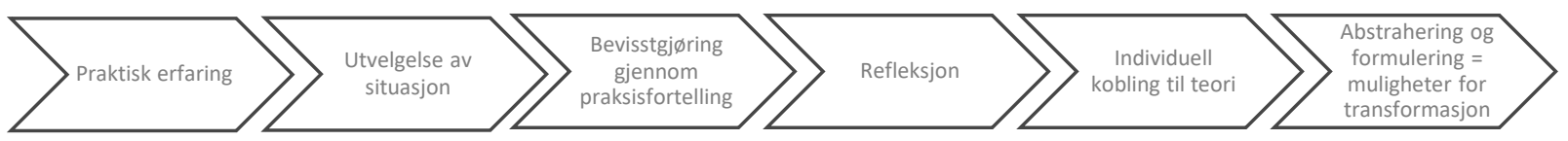

Figur 2. Den første refleksjonsprosessen

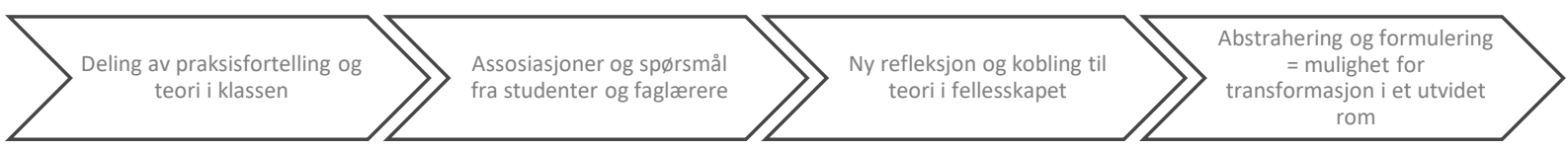

Figur 3. Den kollektive refleksjonsprosessen

\section{Rom for refleksjon - en oppsummerende drøfting}

Vi fant at det skjedde en utvidelse av fortellingene i løpet av refleksjonsøkten da fortellingene ble retolket og refortalt, selv om graden av abstraksjon var varierende. Situasjonene fra klasserommet ble utdypet og utvidet, noe som kan gi grunnlag for generalisering til andre settinger (Gudmundsdottir, 1996). Ved å være deltaker i refleksjonsøkten fikk lærerstudentene erfaringer med læring som en negasjonsprosess (von Oettingen, 2012), med en forståelse av at verden ikke alltid er slik vi trodde den var. Egne forforståelser kunne dermed bli rokket ved.

Studentenes sosiale og kulturelle fellesskap gir en god ramme for meningsskaping og transformativ læring (Mezirow, 1997), og dialogen i klasserommet gir en god kontekst for utvikling av refleksjonsevne og dømmekraft. Ved å lytte til 
andres opplevelser kan egne erfaringer bli utfordret og problematisert (Halmrast et al., 2013), og på denne måten kan studentene fungere som «katalysatorer» for refleksjon (Daudelin, 1996). Dette kunne gjøre det mulig å få innblikk i den Andres forestillingsverden (Arendt, 1996). Andres fortolkninger kan forhindre at egne forforståelser går i ring. For at en overskridende tenkning skal skje, er det derfor sentralt at studentene våger og ønsker å delta aktivt i fellesskapet som klassen utgjør (Illeris, 2012). Rom for refleksjon i et fellesskap avhenger av både klima og læringskultur i klassen (Borko, 2004). Å tone ned vurderingsaspektet var sentralt, da det var læringsaktiviteten og refleksjonen som skulle være i fokus. Engstelse for vurdering eller bedømmelse kan stå i veien for en kritisk holdning til erfaring (Rappel, 2018).

Lærerstudenter er forskjellige, og det var ulikt hvordan den enkelte responderte på andres innspill. Men nettopp fordi kritisk tenkning er krevende, er det viktig å innarbeide en åpen samtalekultur tidlig for studentene (Borko, 2004). Ifølge Dewey (1993) er det viktig å innarbeide vaner som innebærer å bryte vanens makt. Dette vil si å skape en kultur og et læringsmiljø der det er rom for å feile, samtidig som det skapes en forventning om alltid å stille seg kritisk til egne forestillinger og være åpen for andre forståelsesmåter. Her kan tid være en avgjørende faktor (Borko, 2004). Transformativ læring kan være knyttet til klare brudd med tidligere antakelser og vil innebære en endring i forståelse, hvor det ikke er mulig å gå tilbake til forforståelsen. Slike endringer kan også utvikles gradvis over tid (Mezirow, 1990). Læringsutbytte kan ikke garanteres gjennom transformative læringsaktiviteter, men gjennom et kontinuerlig, systematisk arbeid i undervisningen som utfordrer og trigger forforståelse, kan transformativ læring fremmes. Å utvikle et rom for refleksjon må derfor prioriteres, og studenter må få trene seg på å utvikle refleksjonsferdigheter.

Vår studie er gjennomført i en avgrenset og lokal læringskontekst der vi som faglærere har dobbeltroller. Vi har søkt å balansere forholdet mellom nærhet og distanse for å styrke studiens kvalitet. Artikkelen belyser kjente dilemma og universelle problemstillinger i lærerutdanningen, og ved å gjøre forskningsprosessen transparent kan våre funn ha overføringsverdi til lignende settinger. Vår undersøkelse er avgrenset i tid, og derfor blir ikke mer langsiktige endringer fanget opp. Vi vet heller ikke om refleksjonene reelt fører til en endret praksis. Studien viser imidlertid hvordan praksisfortellingen som studentaktiv læringsform kan fungere som en igangsetter der forforståelser og vanetenkning trigges. Undersøkelsen svarer derfor på behov for forskning som konkretiserer hvordan lærerutdannere i praksis kan arbeide med refleksjon og transformativ læring i klasserommet. Flere studier etterlyser forskning på dette området (Allas et al., 2017; Eraut, 2004; Fosse, 2016; Hatlevik, 2018). 


\section{Avslutning}

Denne artikkelen har fokusert på hvordan arbeid med praksisfortellingen kan danne utgangspunkt for refleksjon og transformasjon hos lærerstudenter. På bakgrunn av funnene våre kan vi hevde at det på flere måter var skapt et rom for refleksjon i den observerte undervisningsøkten. Gjennom praksisfortellingene stoppet studentene opp og dvelte ved situasjoner eller hendelser i elevenes klasserom. Interaksjoner i kontekstene ble gjort levende for oss som tilhørere, og det ble satt ord på den ellers tause, erfaringsbaserte forståelsen. Vi observerte at når fortellingene ble delt i den kollektive læringsøkten, skjedde en utvidelse, der studentene ble involvert i hverandres erfaringer og forståelse av situasjonene. Denne felles erfaringen synliggjorde på en konkret måte hvordan situasjoner kan forstås og tolkes ulikt, og at det ikke alltid finnes enkle løsninger, men tvert imot flere mulige forståelsesmåter.

Undersøkelsen indikerer at noen forhold kan påvirke kvaliteten til refleksjonen og den pedagogiske tenkningen. Dette kan blant annet dreie seg om kvaliteten ved selve praksisfortellingen, hvordan fortellingen er bearbeidet og om budskapet er tydeliggjort. Hvordan studentene forstår og finner mening i den pedagogiske teoriens rolle og funksjon i et slikt arbeid, har også betydning.

Et rom for refleksjon og transformativ læring krever et læringsfelleskap som både støtter og utfordrer. Transformative læringsaktiviteter kan skape endringer i forståelsen hos den enkelte student, som plutselige brudd eller mer gradvis over tid, men dette forutsetter at de utvidete fortellingene og den kollektive refleksjonen skaper en ubalanse slik at forforståelsen forstyrres. Derfor må det tidlig utvikles en kultur for å utfordre og så tvil, under forutsetning av et romslig og aksepterende miljø. Dette er vesentlige aspekter ved læring og transformasjon. Personlige erfaringer kan bidra til involvering, og til at refleksjoner og diskusjoner fremstår som relevante og meningsfulle. Samtidig kan refleksjonsprosesser sette i gang forsvarsmekanismer når egne opplevelser og forståelser blir utfordret. Men hvis studentene får øynene opp for at dette dreier seg om mer generelle pedagogiske problemstillinger, skapes muligheter for overskridende tenkning. Det er ikke lenger egne handlinger som utfordres. Fokuset rettes heller mot pedagogisk tenkning på et mer generelt nivå, som kan ha overføringsverdi til lignende situasjoner i andre kontekster.

Det er behov for mer forskning som undersøker hvordan refleksjonsprosesser kan settes i sving for å støtte konstruksjon av pedagogisk kunnskap. Lærerarbeid er en tenkende praksis, og pedagogikkundervisningen er en praksis som skal fremme pedagogisk tenkning og transformative læringsprosesser. For studentenes læring og utvikling har det derfor betydning å videreutvikle en 'refleksjonspedagogikk’ i lærerutdanningen. 


\section{Om forfatterne}

May-Britt Revheim Brekke er høgskolelektor i pedagogikk ved Høgskulen på Vestlandet. Hennes forskningsinteresser er knyttet til allmenne pedagogiske spørsmål, undervisning og læring, ulike kunnskapsformer, refleksjon og overskridende tenkning.

Institusjonstilknytning: Institutt for pedagogikk, Høgskulen på Vestlandet, Postboks 7030, 5020 Bergen.

E-post: $\underline{\text { mbrb@hvl.no }}$

Marianne Leikvoll Eide er høgskolelektor i pedagogikk ved Høgskulen på Vestlandet. Hennes forskningsinteresser har utgangspunkt i allmenn pedagogikk i lærerutdanningen, undervisning og læring, og med særlig fokus på vekselspill og samspill mellom det teoretiske og praktiske kunnskapsgrunnlaget for profesjonsutøvelsen og utvikling av lærerprofesjonalitet.

Institusjonstilknytning: Institutt for pedagogikk, Høgskulen på Vestlandet, Postboks 7030, 5020 Bergen.

E-post: $\underline{\text { mle@hvl.no }}$

\section{Referanser}

Allas, R., Leijen, Ä. \& Toom, A. (2017). Supporting the construction of teachers’ practical knowledge through different interactive formats of oral reflection and written reflection. Scandinavian Journal of Educational Research, 61, 600-615.

Arendt, H. (1996). Vita active - Det virksomme liv. Oslo. Pax Forlag.

Ausubel, D. P. (2000). The acquisition and retention of knowledge. A cognitive view. Dordrecht: Kluwer Academic press.

Birkeland, L. (2004). Fortællinger som fænger og fanger. Praksisfortællinger og personaleudvikling i børnehaven. I S. I. Mørch (red.), Pcedagogiske praksisfortecellinger (s. 110128). Århus: Systime Academic.

Borko, H. (2004). Professional development and teacher learning: Mapping the terrain. Educational Researcher, 33(8), 3-15.

Brekke, M. R. (2017). Pedagogisk refleksjon i «det undersøkende rommet». I H. Sæverot \& T. Werler (red.), Pedagogikkens språk (s.240-255). Oslo: Gyldendal Akademisk.

Bruner, J. (1997). Utdanningskultur og læring. Det utdanningsvitenskapelige bibliotek. Oslo: Ad notam Gyldendal.

Burchell, H. \& Dyson, J. (2000). Just a little story: The use of stories to aid reflection on teaching in higher education. Educational action research, 8(3), 435-450.

Creswell, J. (2014). Research Design. Qualitative, Quantitative, \& Mixed Methods Approaches. Fourth ed. Lincoln: Sage Publications.

Daudelin, M. W. (1996). Learning from experience through reflection. Organizational Dynamics, 24(3), 36-48.

Dewey, J. (1933). How we think: A Restatement of the relation of reflective thinking to the educative process. Boston: D. C. Heath and Company. 
Dewey, J. (1974). Erfaring og opdragelse. Dansk utgave ved Hans Fink. København: Christian Ejlers Forlag.

Eide, M. L., Brekke, M. R. B. \& Holthe, A. (2017). Teoriens manglende plass i praksissamtalen. Acta Didactica Norge, 11(1), Art. 9.

Eilifsen, M. (2015). Praksisfortellingen - mulighet for sammenheng mellom teoretisk og praktisk kunnskap. I E. E. Ødegaard \& M. S. Økland (red.), Fortellinger fra praksis. Trøbbel, vendepunkt og stolthet (s. 195-213). Bergen: Fagbokforlaget.

Eraut, M. (2004). Transfer of knowledge between Education and Workplace settings. I H. Rainbird, A. Fuller \& A. Muro (red.), Workplace learning in context (s. 201-221). London: Routledge.

Fangen, K. (2010). Deltagende observasjon (2. utg.). Bergen: Fagbokforlaget.

Fennefoss, A. T. \& Jansen, K. E. (2004). Praksisfortellinger - på vei til innsikt og forståelse. Bergen: Fagbokforlaget.

Fosse, B. O. (2016). Transformering av kunnskap mellom campus og skole i lærerutdanningen. Acta Didactica Norge, 10(2), 235-251.

Grimen, H. (2008). Profesjon og kunnskap. I A. Molander \& L. Terum (red.), Profesjonsstudier (s. 71-86). Oslo: Universitetsforlaget.

Gudmundsdottir, S. (1996). The Teller, the Tale and the One Being Told: The Narrative Nature of the Research Interview. Curriculum Inquiry, 26(3), 293-306.

Halmrast, G., Taarud, R. \& Østerås, B. (2013). Bruk av praksisfortellinger for å skape sammenheng mellom praksis og teori i førskolelærerutdanningen. Norsk Pedagogisk Tidsskrift, 97(1), 17-27.

Hatlevik, I. K. R. (2018). Transformativ læring. Uniped, (04), 384-400.

Heggen, K. \& Raaen, F. D. (2014). Koherens i lærarutdanninga. Norsk Pedagogisk Tidsskrift, 98(1), 3-13.

Hovdenak, S. S. \& Fosse, B. O. (2014). Lærerutdanning og lærerprofesjonalitet i spenningsfeltet mellom ulike kunnskapsformer. Norsk Pedagogisk Tidsskrift, 98(02), 66-77.

Illeris, K. (2012). Læring. Oslo: Gyldendal Akademisk.

Jansen, K. (2008). Narrativ og Tekst. Norsk Pedagogisk Tidsskrift, (01), 27-39.

Klemp, T. (2013). Refleksjon: hva er det, og hvilken betydning har den i utdanning til profesjonell lærerpraksis? UNIPED, 36(1).

Korthagen, F. A. M. \& Vasalos, A. (2005). Levels in Reflection: Core reflection as a means to enhance professional growth. Teachers and Teaching: theory and practice, 11(1), 47-71.

Kvale, S. \& Brinkmann, S. (2015). Det kvalitative forskningsintervju (3. utg.). Oslo: Gyldendal akademisk.

Kvernbekk, T. (2001). Erfaring, praksis og teori. I T. Kvernbekk (red.), Pedagogikk og larerprofesjonalitet (s. 146-163). Oslo: Gyldendal Akademisk.

Kvernbekk, T. (2011). Filosofisk om teori og praksis. Bedre skole, (2), 20-25.

Kvernbekk, T. \& Frimannsson, G. (2013). Narrative: A Brief Introduction. Scandinavian Journal of Educational Research, 57(6), 1-3.

Lin, L. \& Cranton, P. (2005). From Scholarship Student to Responsible Scholar: A Transformative Process. Teaching in Higher Education, 10(4), 447-59.

Lofland, J. \& Lofland, L. H. (2006). Analyzing social settings : A guide to qualitative observation and analysis (4th ed.). Belmont, Calif: Wadsworth.

Meld. St. 16 (2016-2017). Kultur for kvalitet i høyere utdanning. Oslo: Kunnskapsdepartementet.

Mezirow, J. (1990). How critical reflection triggers transformative learning. I J. Mezirow (red.), Fostering Critical Reflection in Adulthood: A Guide to Transformative and Emancipatory Learning (s. 1-21). San Francisco: Jossey-Bass. 
Mezirow, J. (1997). Transformative Learning: Theory to Practice. New Directions for Adult and Continuing Education, 74, 5-12.

Procee, H. (2006). Reflection in education: a Kantian epistemology. Educational theory, 56(3), 237-253.

Rappel, L. (2018). Transforming thought through reflective experiential learning. Arts and Humanities Open Access Journal, 2(2), 131-136.

Solstad, A. G. (2013). Profesjonsorientert refleksjon i praksisopplæringen - en utfordring for praksisopplæringen. Norsk Pedagogisk Tidsskrift, (2), 97-10.

Ulvik, M., Riese, H. \& Roness, D. (2016). Å forske på egen praksis: Aksjonsforskning og andre tilncerminger til profesjonell utvikling i utdanningsfeltet. Bergen: Fagbokforlaget.

von Oettingen, A. (2012). Almen Pæedagogikk. Pædagogikkens grundlæeggende spørgsmål. København: Gyldendal A/S.

Wittek, A. L. \& Habib, L. M. A. (2012). Undervisningskvalitet som praksis. Norsk Pedagogisk Tidsskrift, (3), 223-236.

Ødegaard, E. E. \& Birkeland, L. (2001). Tusen erfaringer søker fortellinger. Bergen: Høgskolen i Bergen.

Ødegaard, E. E. (2015). Studier av narrative praksiserfaringer. I E. E. Ødegaard \& M. S. Økland (red.), Fortellinger fra praksis. Trøbbel, vendepunkt og stolthet (s. 21-45).

Bergen: Fagbokforlaget. 